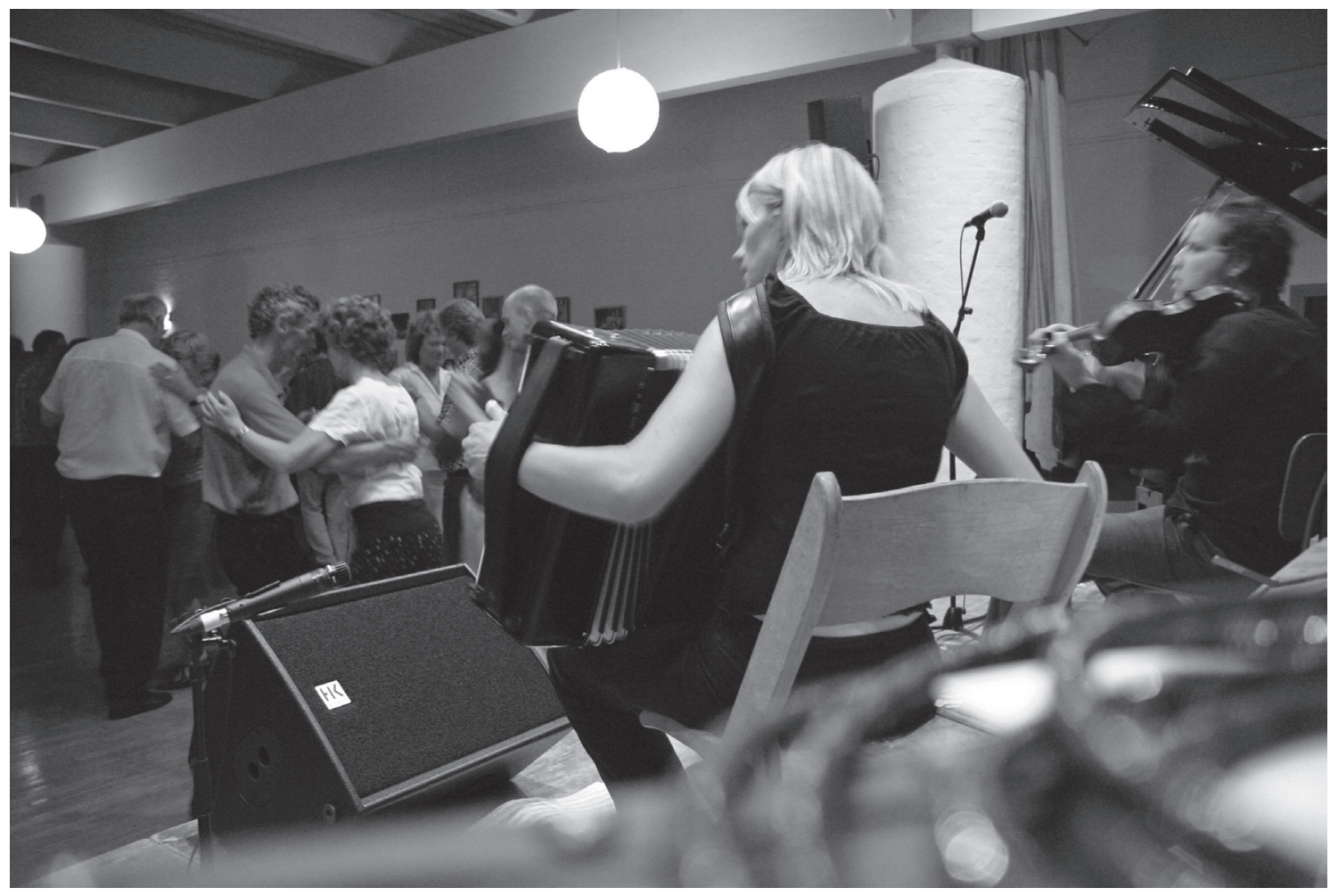

Der spilles op til tango i Vrå 2006

\title{
Tango- en livgivende dans
}




\section{- TANGO ... MEGET MERE END BLOT ELEGANTE TRIN}

"Jeg troede bare, jeg skulle gå til dans ... sådan én gang om ugen ... en fritidsinteresse ligesom alle andre." Sådan fortæller Grethe, der er 52 og lærer.

Men sådan gik det ikke. Grethe blev fascineret af den argentinske tango. Hun går på sit femte år til tangoundervisning én gang om ugen, og hun tager ofte til dansearrangementer forskellige steder i landet. Tangomusikken strømmer ud af bilens højtalere, når hun kører, dog ind imellem afløst af en CD med undervisning i spansk. Grethe skal nemlig sammen med en lille gruppe fra det lokale tangomiljø på sin jomfrutur til tangoens Mekka Buenos Aires i påsken i år. Tangoen er blevet en uundværlig del af Grethes liv.

Mange tangodansere kan berette om deres første møde med tangoen. Ofte beskrives samme lidt tilfældige møde, som Grethe erfarede. Tangoen, den argentinske tango - Tango Argentino - er anerkendt for sin elegance, sin skønhed og udtryksfuldhed, og som tilskuer til dansen bliver mange tryllebundet og fascineret af tangoens magi. Tango er ikke en ny trend. Men den er inden for de sidste 10 år blevet ekstra populær på lige fod med salsa og andre latinamerikanske danse. I det hele taget er det slående at se den bølge af danseaktiviteter, der ses over hele kloden, både i TV, i reklamerne, i dansestudierne, $i$ foreningerne, på diskotekerne og på internettet. Lokalt kan man foruden de latinamerikanske danse også finde danseformer som breakdance, linedance, mavedans, folkedans, swing m.m.

Mere end et århundrede er gået, siden tangoen opstod i storbyen Buenos Aires i Argentina, og den har haft flere popularitets op- og nedture i det forløbne århundrede. Allerede i tyverne havde tango sin første store bølge i Danmark. Det var også i den periode, Jacob Gade komponerede flere tangoer, bl.a. den verdenskendte Tango Jalousi i 1925.

I dag danses den argentinske tango overalt $i$ verden, især i de større byer. I 1990'erne slog tango rigtig rødder i København og har siden fået solide platforme andre steder i landet, bl.a. på Fyn og i Trekantområdet. Søger man på nettet på det danske begreb argentinsk tango, får man 5.090.000 hits.

Tangoen handler egentlig ikke om sundhed og da slet ikke om skridtmålinger, kolesteroltal eller lignende. Men videnskabelige undersøgelser peger dog på, at argentinsk tango fremmer sundhed på forskellige områder. Effekten af et kommunebaseret argentinsk tangoprogram med to timers dans to gange om ugen gav en gruppe ældre mellem 62-91 år bedre balance, større selvtillid og mindre faldtilfælde end en tilsvarende gruppe, der fik gangtræning. Tangogruppen fik også forbedret muskelstyrke og øget ganghastighed set $\mathrm{i}$ forhold til ganggruppen (McKinley et al. 2008).

Det er ikke nyt, at dans, musik og kulturaktiviteter fremmer sundheden. Musik får patienter med hjerneblødning hurtigere på benene, dans styrker balancen for folk med Parkinson, og korsang kan give kræftpatienter mod på livet. Det er konklusionen i flere internationale forskningsprojekter (www.nice.org.uk).

Hensigten med denne artikel om den argentinske tango er at belyse, hvad der kan opstå, når mennesker mødes $\mathrm{i}$ forskellige netværk og udfolder en fælles interesse. Og i denne aktivitet handler samværet ikke om sundhed, men om at danse. Men dansens sjæl, form og organisering kan imidlertid "utilsigtet " give bedre sundhed og velvære. 


\section{METODE}

Min egen introduktion til dansen skete for sekssyv år siden, hvor jeg sammen med min mand meldte mig til et FOF tangokursus. Jeg havde umiddelbar meget let ved at lære trin og trinkombinationer, men havde meget svært ved at hengive mig til mandens føring, og det var nærmest en terapeutisk proces at skulle afgive den kropslige styring. I dag er tangoen en stabil grundpille i forhold til mit velbefindende. Især er jeg fascineret af den bevægelseskommunikation, der eksisterer - kombinationen af krop og kommunikation, krop og intellekt samt krop og netværk. Jeg har deltaget i mange workshops med argentinske undervisere, jeg har fordybet mig i tangokulturen i Buenos Aires og har været aktiv i oprettelse af Trekantområdets tangoforening - La Luna, der i dag tilbyder et rigt repetoire af tangoaktiviteter: undervisning, workshops, La Práctica (øvested), Milonga, koncerter m.m. Mange, der er aktive tangodansere, kan berette om en tilsvarende indgang, og om hvordan tangoen har ændret deres livsstil.

I denne artikel tager jeg dog en mere neutral position og diskuterer mulige sammenhænge mellem tango og sundhed. Der tages afsæt i Merleau-Pontys fænomenologiske forståelse, der indsætter kroppen og sansningen som menneskets fundamentale adgang til verden. Ud fra denne fænomenologiske position vil jeg forsøge at gå til og beskrive fænomenerne så forudsætningsløst som muligt eller i det mindste være forudsætningsbevidst og søge efter det essentielle, det der holder sig konstant, selv om sammenhængen forandres (Kvale 2009).

Artiklen bygger på feltarbejde foretaget over flere år. Feltarbejde er specielt egnet til at undersøge samspillet mellem mennesker og grupper af mennesker (Wadel 1991). I dette tilfælde vil det sige dansen og interaktionen mennesker

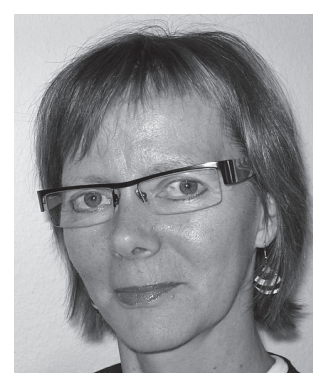

AF

HANNE

PALLESEN

imellem samt dansemiljøet - hvordan påvirker og påvirkes den enkelte af det. Jeg har som feltarbejde deltaget i dansen og undervisningen og har så senere samtalet / interviewet en eller flere om det, som foregik, og hvad de oplevede. Feltarbejde som deltagende observatør kræver, at man er i stand til at være "sociolog på sig selv«, og at man under feltarbejdet stadig analyserer sin egen adfærd og sine egne kulturelle værdier (Wadel 1991). Ligesom ordet deltagerobservationer indeholder to dele, således rummer metoden også to adskilte erkendelsesprocesser. Deltagelse indebærer indlevelse i det ukendte. Observationer forudsætter derimod en distancering til det oplevede, det sete og det hørte foruden registrering af en mængde faktuelle forhold (Hastrup \& Ramløv 1988; Hammerley \& Atkinson 1996).

Min egen fascination for dansen og hvad den gjorde ved mig, var det, der satte mig i gang med at reflektere over tangoens væsen. Det var også det, der fik mig til at påbegynde et feltarbejde med fokus på tango og sundhed. At jeg selv har gennemgået "en slags terapeutisk proces «, da jeg startede med at danse tango, har selvfølgelig betydet, at jeg har været nysgerrig efter at se om andre oplevede noget lignende, men det har også betydet, at jeg har været interesseret $\mathrm{i}$ at høre andre fortællinger. Jeg har ikke interviewet personer, der er holdt op med 


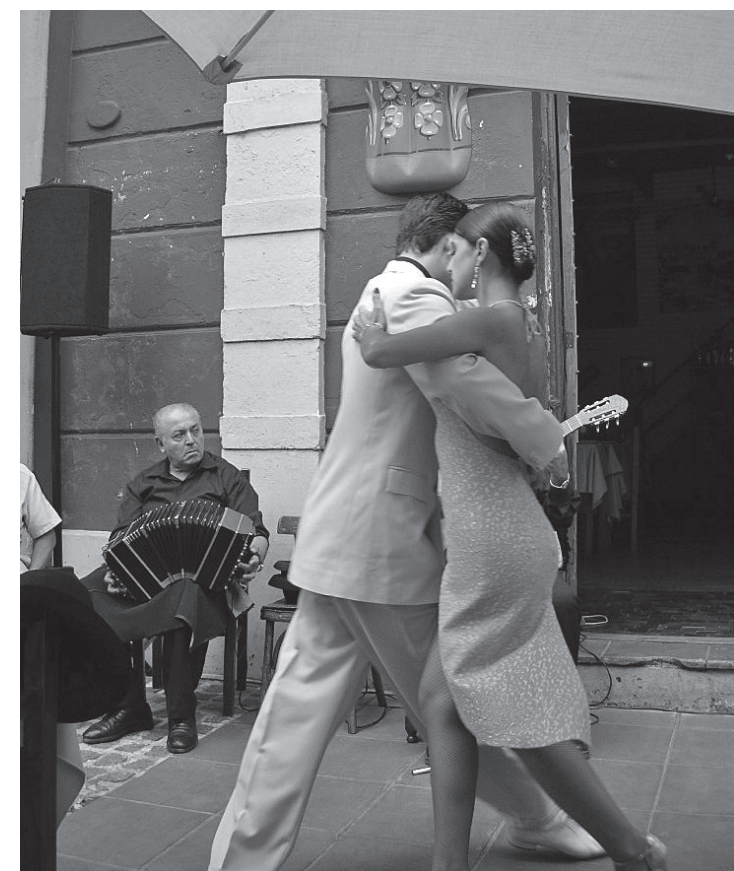

Den argentinske tango danses på gader og stræder.

at danse tango, fordi de mistede fascinationen eller aldrig fik den, netop ud fra en mening om, at det at blive så at sige "indfanget " af tangoen er den argentinske tangos mission, og at denne fascination er netop det interessante at studere i relation til sundhed. Min position i dette feltarbejde blev derfor at fastholde lærlingerollen, både på dansegulvet og i de efterfølgende samtaler. Hermed placerede jeg mig i en position, hvor jeg lærte af informanten og erhvervede mig de kulturelle kundskaber og kompetencer, som informanten gav udtryk for (Wadel 1991).

I forbindelse med deltagerobservationerne har jeg skrevet feltnoter, dvs. en slags dagbogsbeskrivelser uden nogen specifik systematik ud over den kronologiske tid (Emerson et al. 1995).
Med et projekt, der har afsæt i andre menneskers oplevelser, kan man ikke være helt sikker på, hvor man bliver ført hen, og hvilke betydningsfulde temaer informanterne bringer op. Dette gør, at man kan få et mere processuelt metodeforløb. Wadel betegner det som en "runddans" mellem teori, metode og data. Men man kan som forsker hjælpe sig selv ved at have gjort sig sine teoretiske perspektiver bevidst (Wadel 1991).

Deltagerobservationer og de (20) ustrukturede og (6) strukturede interviews er primært foretaget i Danmark, Australien og Argentina.

\section{TANGO SOM NARRATIV}

Tangokulturen har mange fremtoninger, som spiller sammen og påvirker hinanden. Først og fremmest er der dansen - en pardans, som stimulerer til kropslig kommunikation og stor indføling over for hinanden. Så er der musikken, der udfolder en variation af grundstemninger, og endelig er der sangen, der fortolker livet som en fortælling.

Tango knytter sig til Argentina og er der betydningsfuld for den argentinske selvforståelse, men den er også vigtig i forhold til nationaløkonomien, da tangoturismen især i Buenos Aires ikke er så ubetydelig.

En del bøger er også udkommet i Skandinavien om tango (Toxværd 2006; Abadi 2003; Westergård 2009). De fortællinger, der udfolder sig under tangoundervisningen, workshops og i den skandinaviske litteratur, genfortælles i det følgende afsnit om tangoens opståen og genfødsel.

\section{TANGOENS OPSTÅEN OG GENFØDSEL}

"Jeg skal mindst én, bedst to gange om året til Buenos Aires for at opleve den sande argentinske sjæl«, siger Ian. 
Han har egen lejlighed i Buenos Aires, som han selv bruger, når han er der, men ellers lejer ud til andre Tango-besøgende.

Tangoen kom til verden for mere end 100 år siden i de fattige kvarterer i udkanten af storbyen Buenos Aires i en tid (i slutningen af 1800-tallet), hvor Argentina åbnede sine grænser for fri immigration. Indbyggerantallet i Buenos Aires steg i perioden mellem 1869 og 1914 fra 180.000 til 1.576.000 indbyggere (Archetti 2003). Argentina havde på daværende tidspunkt brug for fremgang. For de liberale og fremtidsorienterede politikere betød det, at man måtte importere arbejdskraft i forventning om, at europæerne ville sætte gang i udviklingen og bringe nye dimensioner til kulturen. Immigranterne var imidlertid ikke veluddannede eller højt kvalificeret arbejdskraft, men derimod fattige landarbejdere uden nogen særlige kundskaber eller skolegang, der lod sig lokke af troen på at få egne jordbesiddelser og finde lykken i det fremmede. De blev imidlertid skuffet. Landet var i forvejen ejet af velhavende og konservative familier, endvidere var de ikke spor velkomne af kreolerne, de spanske efterkommere, der gjorde, hvad de kunne for at gøre livet surt for de nyankomne. Immigranterne organiserede sig i fagforeninger, hvilket medførte store forfølgelser og henrettelser. Mange immigranter vendte hjem igen, mens andre blev og slog sig ned. De danske immigranter slog sig ned omkring byerne Necochea, Tandil og Tres Arroyos, hvor klimaet lignede det danske, og hvor de kunne etablere et liv, de kendte hjemmefra. Men de fleste slog sig ned i nærheden af de store byer, først og fremmest Buenos Aires (Toxværd, 2006).

Begrebet arrabal (kvarter i udkanten af byen) møder vi ofte i tangosangene og i beskrivelserne af de forskellige tangostile. I disse kvarterer op- stod en egen subkultur med compadres (gudfædre), el compadrito (en fyr, der fører sig lapset frem), og i denne subkultur, der vanskeligt lader sig beskrive med alle disse forskellige nationaliteter og deres musik, dans og traditioner, skabtes tangoen i de underpriviligeredes liv. Mercedes Sanz ${ }^{3}$, der er født og opvokset i Argentina, men måtte flygte til Europa under militærjuntaen og senere slog sig ned i Danmark, fortæller:

»Tangoen er i dag en hel kultur for argentinerne. Den lever i argentinernes hverdag, måden at gå på, måden at udtrykke sig på, $\mathrm{i}$ byens gader og veje. Den har sin egen mytologi, skabt af de personer, som er beskrevet i dens digte og legender: el malevo, den ærefulde kriminelle, der gerne duellerer for at forsvare en ven eller en kvinde, el compadrito, den smarte fyr, eller om la milonguita pigen, der forlod det fattige kvarter for at kaste sig ud i kabaretlivet samt hendes skæbne og kvindens forræderi over for en mand, der elskede hende. Tangoens tekster handler i høj grad om livet i el arrabal. Teksterne beskriver dens gader og veje, dens nætter, månen eller gadelygterne, men også de fattiges levevilkår. Der synges om byen Buenos Aires, og om nostalgien fra en tabt fortid. Der synges om selve tangoen. Ud over disse tilbagevendende motiver er der mange tekster, som er direkte sociale protester."

Tangoen fødtes som en protest mod de betingelser, som befolkningen i de fattige kvarterer måtte tåle i et samfund i voldsom udvikling omkring 1880 'erne. Som resultat af en overvældende indvandring og et stillestående konservativt samfund opstod en rodløshed i det nye land. De nye argentinere havde brug for at genskabe sig en 
identitet, blande sig med hinanden og skabe noget nyt, og det gjorde de gennem skabelsen af en subkultur af en helt ny musik - tango og dansen, der gav et fælles sprog og kommunikation (Toxværd, 2006).

El choclo 1947. Musik af Ángel Villoldo. Tekst af Enrique Santos Discepolo.

Con este tango que es burlón y compadrito se ató dos allas la ambición de mi suburbio con este tango nació el tango y como un grito salió del sórdido barrial buscando el cielo.

Conjuro extraño de un amor hecho cadencia Se abrió camino sin más ley que su esperanza Mezcla de rabia, de dolor, de fe, de ausencia Llorando en la inocencia de un ritmo juguetón.

Con tu milagro de notas agoreras Nacieron sin pensarlo las paicas y las grelas Luna en los charcos, cayengue en las caderas $\mathrm{Y}$ un ansia fiera en la manera de querer.

$\mathrm{Al}$ evocarte, a tí tango querido

Siento que suenan las baldosas de un bailongo $\mathrm{Y}$ oigo el rezongo de pasado

Hoy que no tengo

Más a mi madre

Siento que viene en punta 'e pie para besarme Cuando mi canto nace al son de un bandoneón
I nedenstående tango sang, oversat af Mercedes Sanz, udtrykkes vemodet, håbet, længslen, som også er den grundstemning, der karakteriserer tangomusikken.

[dansk oversættelse]

Med denne tango, som er drillende og smart, Fik mit kvarters ambition to vinger

Med denne tango fødtes tangoen, og som et skrig for den ud af det lurvede kvarter og søgte mod himlen

Mærkelig sammensværgelse af en kærlighed, der blev til takter

Og åbnede sig vej uden anden lov end sit håb Blanding af vrede, af smerte, af tro og af savn Grædende i uskylden fra en legende rytme

Med dit mirakel af ildevarslende noder Fødtes der uden tanke tøser og kvinder. Der var måne i vandpytterne og rytme i hofterne Og vildt begær i måden at elske på

Når jeg mindes dig. Elskede tango Hører jeg lyden af klinkerne i en milonga Og knurren af min fortid

I dag, hvor jeg ikke længere har min mor

Føler jeg, at hun kommer på tåspids og kysser mig, Når min sang fødes i bandoneonens klang.] 
Tangosangene og musikken tilhører ikke den argentinske folkemusik. Tangoen er bymusik fra La Plata-flodens bredder, dvs. Buenos Aires og byerne i omegnen og strækker sig op til Montevideo i Uruguay - som ligger lige nord for Buenos Aires (Toxværd 2006). Tangomusikken har dog i Argentina karakter af nationalmusik. Tango har sin egen radiokanal og høres i Argentina, som vi i Danmark hører P3 musik.

Argentinerne, der drog ud, tog tango med sig, og allerede i 1911 så man i Paris tangoen udfolde sig som Tango thé, tango diner og tango champagne. Det har især været gennem den komplicerede dans, at tangoen erobrede de europæiske sjæle. Europæerne oprettede tangoklubber, dansestudier og andre forskellige tangomiljøer. Der har været en lang tradition for udveksling af musikere, undervisere og dansere hen over Atlanten. Tangoen har haft flere nedture. Det første militærkup i 1955 betød, at mange dansesteder og klubber blev lukket. Ingen politiske kræfter støttede i den periode tango eller anerkendte dens værdi. Tango var som sådan ikke død i 60'erne eller 70'erne, men blot parkeret på svagt lys for igen at opstå i 1980 både i Argentina, USA, Japan og Europa, bl.a. ved præsentation af det legendariske show Tango Argentino med musikere, sangere og dansere. Det blev starten til tangoens genfødsel i Buenos Aires, men dansen blev også vækket af sin tornerosesøvn i Europa og Danmark (Toxværd 2006).

Man kan med rette stille kritiske spørgsmål ved ovenstående beretninger, hvis man vil se på fortællingen som autentisk historie. I denne sammenhæng skal denne lidt forførende fortælling dog ses som en narrativ konstruktion i relation til argentinsk tango (musik og dans), vel vidende at den kan have flere intentioner, såsom kommercielle og identitetsmarkerende, ud over at være dansens fortælling.
I dag eksisterer der et globalt tangonetværk godt hjulpet af de moderne kommunikationsmidler. Og vi ser en endnu større udveksling af musikere, danse og undervisere hen over den ganske klode. På trods af tangoens op- og nedture i det offentlige rum og på trods af det faktum, at tangoen primært danses i de store byer i Argentina, tilskrives tango på lige fod med fodbold en central betydning for den nationale argentinske selvforståelse. Med udgangspunkt i driblebevægelse, som ses både i fodbold og tangoen, taler man i Argentina om tango-fodbold (på samme måde som en brasilianer identificeres sin med samba-fodbold). Både tango og fodbold er et ritual og et spil, der gør kropslig og symbolsk kommunikation mellem deltagerene mulig (Archetti 2003).

FN skrev i 2009 tangoen på listen over verdens kulturarv.

\section{TANGOENS VAESEN OG FORM}

"Det kan godt være forvirrende i begyndelsen, at argentinsk tango er så tæt og intens. Mens man danser, opnår man en intimitet, som man ellers kun opnår med sin kæreste. Det er vigtigt, at man gør sig klart, om man er her for at danse eller for at score. Det var det i hvert tilfælde for mig. Det fede ved tangoen er, at kommunikationen med partneren er så vigtig. Man er virkelig nødt til at øve og finpudse figurerne og trinene. Vi arbejder meget med de små detaljer." Torben, 32 år, studerende, har danset tango med en veninde $\mathrm{i}$ et år.

Tangoen har ingen fast opskrift. Det handler om at kommunikere uden ord. Man kan lære spillereglerne - danseretning, figurer, trin-kombinationer etc. Dansen skabes derimod i et samspil mellem de to dansepartnere og musikken. Rollefordelingen er krystalklar. Manden fører, og kvinden følger. Begge er omsorgsfulde og hensynta- 
gende. Så enkelt beskriver Carlos Costes, der er danseunderviser i Buenos Aires og flere gange har afholdt workshops i Danmark, tangoen.

\section{OMFAVNELSEN}

At danse tango er kropslig kommunikation - eller rettere bevægelseskommunikation. Uanset om man danser med åben eller tæt omfavnelse. Alt udspringer af omfavnelsen (Abadi 2003). Den er nøglen til at danse, til at nyde at danse, at sikre at ens partner har nydelse og at sørge for, at andre har nydelse ved at se dansen. Omfavnelsen er den teknik, der gør det muligt for manden at kommunikere til kvinden, hvad han foreslår, at der skal ske, altså hvorhen og hvordan han ønsker, at parret bevæger sig (Toxværd 2006). Gennem mine deltagerobservationer oplevede jeg, at gennem omfavnelsen kan kvinden mærke mandens drivkraft og energi, samt hvorvidt og hvordan hun skal støtte manden. F.eks. at danse mere markeret, hvis han har svært ved at følge musikkens puls. Hun registrer, at når manden holder en kort pause i en position, så er det signalet til, at hun kan tage initiativ til ornamenter og små figurer.

Noelle fra en tangoklub i Perth beskrev følgende:

"Der er kun nogle bestemte, der danser med mig ... Jeg er vist for ballroomagtig. Jeg har jo danset ballroom tidligere, og jeg holder jo mit bryst og nakke sådan tilbage, sådan lidt kontrolleret og distanceret ... Det tror jeg ikke, mænd kan li'. Det er i hvert tilfælde derfor, jeg tror, at nogle bestemte mænd ikke kommer og byder mig op. Brad, som du kender, sagde 'tak for dansen' flere gange efter 1. dans (normalt danser man et sæt på 3-4 danse). Senere fandt jeg ud af, at han gerne ville date mig, men han kunne ikke li’ min måde at danse på.«
Når jeg så Noelle danse, virkede det også, som hun kropsligt holdt en vis distance og derfor heller ikke mentalt gav sig selv mulighed for at hengive sig til manden og til dansen. Om hendes erfaringer fra ballroom dans er årsagen til, at hun kun blev budt op af bestemte mænd, er det svært at gisne om, men beskrivelsen vidner noget om, at omfavnelsens karakter er betydningsfuld.

Omfavnelsen beskrives af mange undervisere som en vis spænding først og fremmest som en lille pres mellem hænderne i den åbne side af omfavnelsen, der skaber en stabil referenceramme parterne imellem. Men omfavnelsen fremmer også den psykologiske spænding - forførelsen, forstået på den måde, at når manden viser hensyn og opmærksomhed over for kvinden, tager initiativet og ansvaret for, at dansen går godt, så kan kvinden hengive sig til dansens karakter og mandens føring. Det giver parret mulighed for ligeværdig udveksling på trods af de forskellige roller, hvor manden har førerrollen, og kvinden følger.

\section{MANDEN FØRER, OG KVINDEN FØLGER}

Flere nybegyndere fortalte mig, at rollefordelingen i begyndelsen var en udfordring og kunne opleves kontroversiel og stødende; især for den kvinde, der gerne vil (er vant til at) stå for styringen. Forsøger hun at styre, gør hun manden usikker over for udfordringen til at tage styringen.

Mange har også oplevet, at tangodansen godt kan få et element af terapi, hvilket kan være nødvendigt, uden at tangoen dog er terapi. Flere kvinder fortæller om, at manden er "gået fra dem « midt under en dans ofte med et lødigt påskud, men hvor det for kvinderne har været klart, at manden gik, fordi kvinden ikke kunne lade være med at tage føringen. Oplevelsen gjorde ofte kvinderne vrede, men betød også, at de efterfølgende arbejdede på at afgive kontrol- 


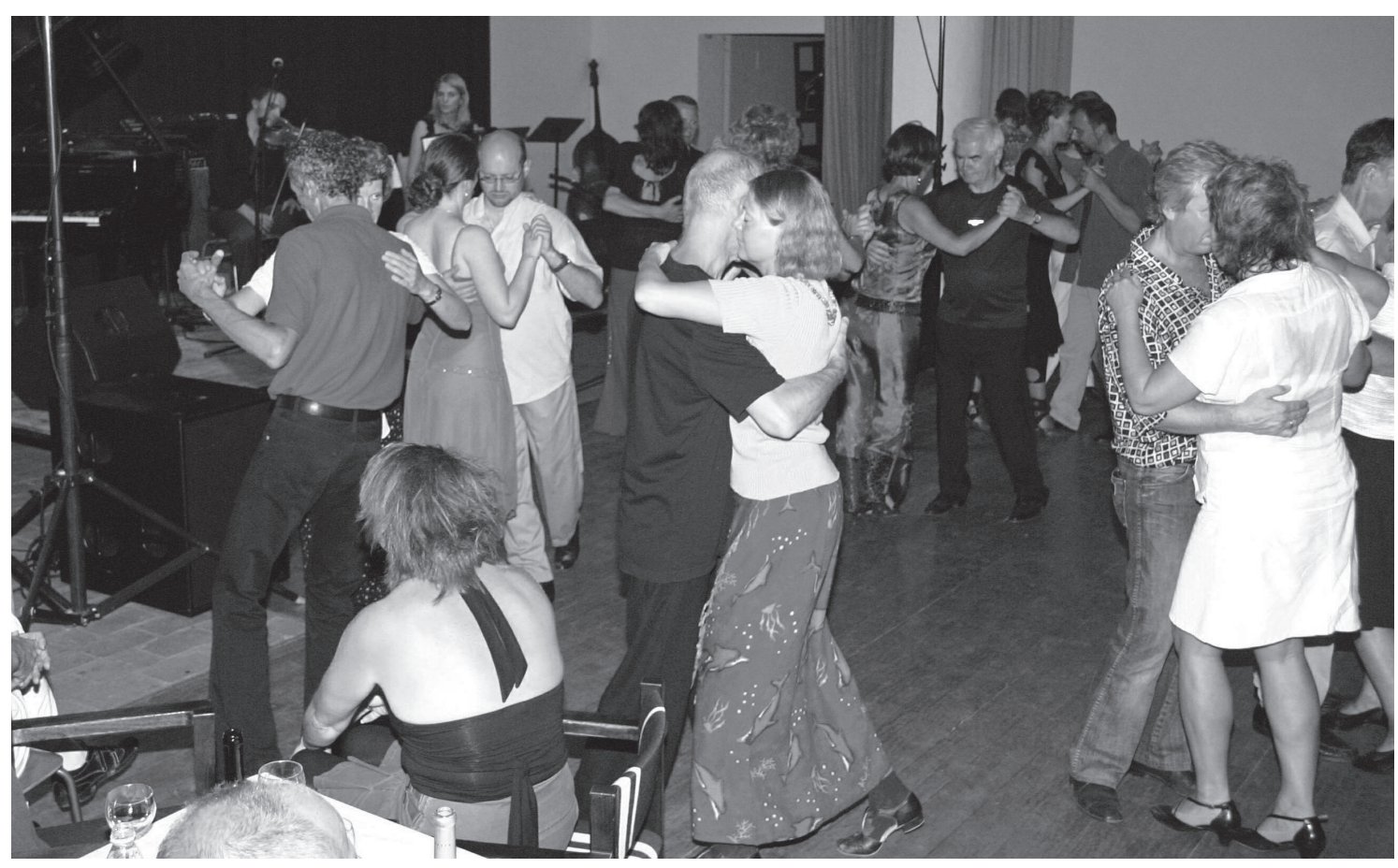

Der danses tango i Vrå 2006.

len. I undervisningsforløb sås også par, der var i krise og ikke kunne få bestemte trin til at lykkes sammen. Ofte byttede de partner for en stund og fandt på den måde frem til at løse problemet, andre søgte råd hos underviserne, og enkelte valgte at få soloundervisning.

Kvinderne fortalte også om den udfordring, der ligger $i$ at skulle kunne danse med mange forskellige mænd. Det kræver en særlig tilstand af beredskab og indføling fra kvindens side. Hun skal ikke kun danse med en mand, der sætter dagsordenen, men gerne med mange forskellige mænd, men hver har sine forskellige kropslige udtryk og fortolkning af musikken. Hun skal endvidere danse baglæns og ofte på høje hæle. Hun skal både stole på sin egen kontrol og balance og samtidig stole på, at manden ikke fører hende ind i nogen eller noget. Og for kvinder er der meget på spil, da mænd kan undlade at byde hende op, hvis hun ikke lever op til deres forventninger.

Omvendt fortalte mændene om de overvejelser, de gjorde sig, og de frustrationer, de oplevede, når de oplevede, at dansen ikke kunne fungere med en bestemt kvinde. Hvis det så at sige var en »ligegyldig kvinde«, som de ikke forventede at skulle danse med igen, så handlede det om at finde et niveau, som de kunne være fælles om og så ellers få dansen afsluttet på en god måde. Det var mere problematisk, når det dre- 
jede sig om en kvinde, de ville møde igen i deres eget nære dansemiljø, så havde de ingen problemfrie løsninger. Mange havde også oplevet, at en kvinde havde sagt nej tak til en dans. Selv om de godt vidste, at det kunne der være mange forskellige grunde til, så erkendte de også, at det oftest føltes som en afvisning af dem som danser.

\section{FRA BEGYNDER TIL EKSPERT}

Nybegyndere skal foruden at lære trin, kropskontakt, de uskrevne regler på milongaen også lære tangomiljøet at kende. Hver tangoklub har sin La Práctica, hvor man kan komme for at øve dansen mindst én gang om ugen. Tangoclub Perth, som dækker en stor befolkningsgruppe havde to La Práctica to gang i ugen, foruden en Midmilonga ${ }^{4}$ hver onsdag og en Milonga hver anden lørdag. En mindre klub som La Luna i Kolding har La Practica hver søndag og en Milonga en gang om måneden. Både i Perth og i Kolding stiller erfarne dansere på La Práctica sig til rådighed; hjælper nybegynderne både med trin, holdning, sko, og fortæller om deres erfaringer med undervisnig og forskellige dansesteder. Nybegyndere får mulighed for at stille spørgsmål, undre sig og gå i dialog. Den erfarne rådgiver på en måde, så den nye føler sig tryg og accepteret, også på trods af kritiske spørgsmål. Mange danske informanter fortalte også, at de havde et princip om at danse mindst en dans med en nybegynder, især når de var til La Práctica. De fortalte, at de selv kunne huske, hvordan det var at være ny, og hvordan dansen med en erfaren danser kunne få løsrevne trin til at blive en flydende dans, de kunne nyde. Mange kunne også navngive de første erfarne dansere, der havde givet dem en uforglemmelig oplevelse af dansen.
Oplæringen i tango har karakter af perifer deltagelse, som beskrevet af Wenger og Lave (Wenger og Lave 1998 og Lave 1999), hvor det tillades, at nybegyndere er nybegyndere i ordets egenlige betydning og får lov til at deltage uden større forpligtelse, men med undren og spørgsmål. Deltagelsen er baseret på situeret forhandling og genforhandling af mening, også når den primært er kropslig. På den måde er forståelse og erfaring altid i konstant interaktion og yderst væsentlig for hinanden. Ifølge Wenger og Lave ophæver begrebet deltagelse således den skarpe adskillelse mellem hjerne og krop; indre betragtninger og engagement; abstraktion og erfaring. Personen, handlinger og verden er inddraget $\mathrm{i}$ al tanke, tale, viden og læring.

\section{TEGN, KODER OG RITUALER}

I samspillet parret imellem handler det om at kunne tyde tegn. Disse tegn læres gennem erfaring (Westergård, 2009). Det kan være lidt vanskeligt at beskrive disse tegn og især for en nybegynder at forstå og tolke dem. En del kvinder fortæller, at det handler om at være rolig, afventende og mærke efter mandens tegn, f.eks. at manden flytter sin vægt over på sit venstre ben, kvinden følger med og afventer så signal på, om manden lægger vægten frem eller tilbage og dermed tegn til bevægelsens retning. Når kvinden har lært disse grundsignaler, oplever hun ofte, at bevægelserne kommer af sig selv. Mændene beskriver derimod en slags dialektisk samspil mellem egen intension og kvindens medspil (»hvor vil jeg bevæge mig hen, på hvilken måde, hvor er der plads og følger hun med«).

Tangoballet - milongaen er også fyldt med tegn og koder, som skaber et rituelt rum for den verden, som dansen og de mange transaktioner finder sted i. Disse regler er uskrevne, men eksi- 
sterer i nogenlunde samme form, uanset om milongaer er placeret i Kolding, Berlin, Sydney eller Buenos Aires.

En milonga er et dansested, hvor der danses argentinsk tango. Rummet er typisk indrettet efter samme princip som en kabaret. Salen har i midten et dansegulv, og rundt om dansegulvet er der borde og stole, og der er en bar. Nogle steder er der også en scene til orkestret. Det første man møder, er garderobe og kassen, hvor man betaler entre, normalt $40 \mathrm{kr}$. Forskellige materialer og løbesedler om undervisning og kommende arrangementer er lagt frem. Salen er veloplyst, så man kan få øjenkontakt med potentielle dansepartnere, men alligevel indrettet intimt og hyggeligt. Man finder et godt bord, hvor man kan se alle og blive set. De, der kender hinanden, starter dansen. De, der er på milongaen for første gang, er afventende og ser på de dansende. Manden er den, der indleder kontakten, og det gør han på afstand ved at få øjenkontakt med den udvalgte kvinde. Gengælder hun invitationen, rejser han sig og bevæger sig over mod hendes bord. Hun rejser sig, og de begynder at danse. De danser en tanda, det vil sige et sæt med normalt fire danse. Mellem hver tanda kommer der en cortina (»(lyd)tæppe«) på 20 sekunder med noget helt andet musik (f.eks. jazz eller swing), hvor de så går hvert til sit. Er manden usikker på, hvordan kvinden danser, kan han vælge at byde kvinden op efter de første to danse i tandaen, så risikerer han ikke så meget.

Disse ritualer om inkliknationer er svære for nybegynderen at forholde sig til. Hvorfor så formelt og besværligt? Ritualerne og de uskrevne regler handler om at skabe tryghed og sikre sig, at ingen føler sig afvist, så ingen bliver kompromitteret og taber ansigt (Abadi 2003; Westergård 2009).

Mange antropologer har været optaget af ri- tualer og deres betydning. Ritualer betragtes som rammer, der kan styre menneskers sociale bevægelse i overgangssituationer fra f.eks. en position og rolle i samfundet til en anden. Allerede i studier fra 1908, beskrevet første gang af Van Gennep i bogen Les Rites de Passage (Van Gennep 1960), præsenteres analyser af, at når der sker brud i et menneskes livsforløb, skaber ritualer overgange, som socialiserer og modner. Disse overgange har ritualer og offentlige ceremonier, der tjener det formål at overføre en person fra én status til en anden, ved at personen deltager i processer, som ofte er meget kropsligt orienteret. I disse overgange til en ny livsfase er personen særligt sårbar og potentielt "farlig" for samfundet, da personens status og rolle $\mathrm{i}$ samfundet på dette tidspunkt er uklar. Ritualer kan medvirke til, at personen får mulighed for at udfylde nye, forskellige roller $\mathrm{i}$ forskellige livsfaser.

Tegn, koder og ritualer indlejret $\mathrm{i}$ tangoen kan anskues på samme måde. De skal sikre, at den nye danser trygt kan træde ind i tangoens univers, og med en hensyntagende adfærd accepteres af de øvrige dansere og kan have tæt kropslig kontakt og hengive sig til dansen uden "fare " for at blive misforstået.

Læringsprocessen, læringsmiljøet, tangoens organisering og miljøet finder jeg har karakter af en overgangsrite. Milongaen er i sin struktur konservativ og rituel og dermed på én gang tryghedsskabende og udviklende. Undervisningen i tango og La Práctica finder jeg er identitetsskabende. Ritualerne og de uformelle regler er nok konservative, men tangoen får også inspiration gennem andre miljøer, såsom tangomusikmiljøerne, internationale workshops, arrangementer, hvor tangoen er involveret med andre discipliner, såsom kunst og musik, og bliver på den måde bæredygtig fremover. 


\section{HVEM DANSER SÅ TANGO OG HVORFOR?}

I en undersøgelse foretaget i Holland og Tyskland identificerede man (Kreutz 2008), at tangodansere var veluddannede og havde et højt socioøkonomisk niveau. De var optaget af tangoen på alle måder, både kropsligt og følelsesmæssigt, og de var motiveret til at dyrke tango på samme måde, som man havde fundet ved andre undersøgelser, hvor deltagerne hengav sig til sang- og musikaktiviteter. De fleste startede med at danse tango, efter de var fyldt 30 år. Investering i tangoen $i$ forhold til tid og penge påviste, at tango var en særdeles vigtig fritidsaktivitet for deltagerne, og tangoen var deres primære fritidsaktivitet. Som motivation for at fortsætte med at danse tango markerede de fleste "stress reduktion" og "afslapning" som centrale temaer, men også "fornøjelig atmosfære» og »forbedret humør « (improving mood) rangerede højt. Og stereotype temaer, som ofte forbindes med tango, såsom kønslig intimitet og erotisk dans, blev ikke nævnt som vigtig faktor i forhold til at praktisere tango (Ibid.).

Der kan argumenteres for, at netop fordi tango er langt mere helhedsorienteret, og at det er et sanseligt kropssyn, der kendetegner dansen, så byder tangoen ind med noget andet end den mere biologiske sundhedsforståelse.

\section{TANGOFAMILIEN - ET MULTIKULTURELT NETVAERK}

»Tango er en god måde at glemme alt det, som man ellers tænker på. Vi har rejst flere gange: Australien, New Zealand ... You name it. Det er fantastisk, at man kan danse og lave sjove ting med et fremmed menneske, som man aldrig har snakket med. Vi danser også derhjemme et kvarter hver dag, ellers bliver jeg helt umulig. Det er god terapi. Jeg arbejder i København en del af ugen og har mine tangosko med, så jeg kan danse derovre.«

Søren, 52 år fra Odense, fysiker, har danset tango med sin kone i syv år.

Tangoen er for Søren både rekreativ og et forum, hvor han møder nye mennesker.

Den argentinske tango i Danmark er baseret på græsrodsbevægelser og frivillig arbejdskraft. Er man interesseret $i$ at etablere og udvikle et tangomiljø lokalt, er det forholdsvis let at etablere en forening, at låne eller leje billige undervisningslokaler og dansesale. Undervisning kan være privat eller etableret gennem voksenundervisningsorganisationerne FOF, LOF m.m. Og har man så fået La Práctica i gang, så danserne kan samles, så har man allerede et lille netværk. Via moderne kommunikationsmedier som emailnyheder og facebook er det hurtigt og let at kontakte andre tangonetværk på tværs af bygrænser, regionslinier og landegrænser. Tangomiljøet består både af transnationale aktiviteter og medlemmer og internationale kontakter.

Netværket er netbaseret, fysisk baseret på forskellige undervisnings- og dansemiljøer og baseret på den kropslige kommunikation. Danserne i miljøerne inspirerer hinanden og tangomiljøerne på tværs af de forskellige lokale, nationale og internationale grænser. De smitter også gensidigt hinanden og har stor betydning for, at den enkelte danser oplever velvære og vitalitet gennem tangodansen, tilknytning til miljøet og udvikler »en slags tangodanser-identitet«.

\section{NETVAER OG SALUTOGENESE}

Nyere netværksteorier belyser sammenhæng mellem sundhed og netværk ${ }^{5}$.

Via det amerikanske Framingham Heart Study påvistes det, at venner og netværk var mere 
nødvendige $\mathrm{i}$ forhold til at forudsige, hvem der var i risikogruppen end kolesteroltal eller kromosomer. Det var bedre at vide, hvem der var venner med hvem. Hvis en mand blev tyk, øgedes risikoen for at hans kone også blev tyk med 37 procent.

Der er ikke undersøgt for den slags sammenhænge i tangomiljøet, men det er nærliggende at tænke sig samme virkningsmekanisme. Hører man om de positive beretninger om, hvordan tangoen har påvirket ens livsstil, så man nu bevæger sig mere, opsøger dansesteder og nye miljøer og møder nye mennesker, så smittes man formodentligt positivt af det.

I denne artikel peges der på, at dansens væsen og form, læringsprocessen, samværet og netværket er centrale temaer for personens udfoldelse. Man kan i dette perspektiv næppe betragte kroppen som alene et biologisk og målrettet redskab for det enkelte menneske. Den er i høj grad underlagt sociale og kulturelle strukturer, historiske forandringer, politiske strømninger, filosofiske, etiske og rituelle rammer.

Sundhed er i dette perspektiv ej heller kun et biologisk fænomen. Mere end 20 år er gået, siden den amerikansk-israelske sociolog Aaron Antonovsky præsenterede sin salutogenetiske teori om "sense of coherence" (oplevelse af sammenhæng) som en global orientering mod at anskue verden, begrundet $\mathrm{i}$ den måde hvorpå mennesker ser, at deres liv har en positiv betydning for deres helbred (Antonovsky 1979). Han præsenterede en teori, hvor sundhed ikke kun er et spørgsmål om risikofaktorer for sygdom (fedme, for lidt motion, forhøjet blodtryk, rygning $\mathrm{mm}$.) eller fravær af sygdomme, men et spørgsmål om modstandskraft og ressourcer. Antonovsky fandt, at modstandskraft beror på den enkeltes oplevelse af sammenhæng, dvs. den enkeltes oplevelse af tilværelsen som meningsfuld, forståelig og håndterbar. Sundhed er i denne forståelse ikke kun en egenskab ved mennesket, men handler om, hvordan mennesket handler og lever. Det giver mening også at stille andre spørgsmål, når man som enkeltperson forholder sig til egen sundhed:

Kan man gennem sin adfærd finde en balance i de biologiske systemer, så man så at sige genskaber sine egne grundbetingelser i forhold til f.eks. kost, motion og hvile? Og kan man gennem sin adfærd overskride disse grundbetingelser på et mentalt og et socialt plan, så man bringer glæde, fascination, nydelse og kreativitet i hverdagen også? Kan man gennem aktiviteter, der kalder på det meningsfulde, følelser og netværk skabe sundhed?

Den argentiske tango - musikken, sangen og dansen - har et sanseligt kropssyn og en livgivende karakter, der vækker glæde og rekreation. Den tillader kropslig nærhed ud fra bestemte rammer og indøver indfølelse over for andre mennesker. Dansen udfolder sig i et læringsmiljø, hvor både nybegynderen og den erfarne har sin betydning, og hvor der kan forhandles meninger. Netværk overskrider lokale, regionale, nationale grænser. Dansen giver også - alt efter hvor mange timer man danser om ugen - en bedre kondition.

Alt sammen gør det dansen til et eksempel på sundhedsfremme, også selvom det ikke er tangoens intension.

Og måske er dansens livgivende karakter også forklaringen på, at mange forskellige danseformer er blevet så populære for tiden.

\section{AFSLUTTENDE}

Denne artikel argumenterer ikke for, at alle skal danse tango eller gå til humør-dans i DGI- regi. Den opfordrer ej heller til, at man skal overhøre de sundhedsprofessionelles råd. 
Sundhedsfremme er en målsætning for mange forskellige faggrupper og professioner, og der er kamp om, hvilke faggrupper og interessenter der har ejerskab til sundhedsarbejdet.

Overlæge Bente Klarlund Petersen, der igennem de sidste 10-15 år har slået til lyd for den biologiske sundhedsforståelse, maner nu til besindighed $\mathrm{i}$ forhold "sygeligt fokus på krop og sundhed" (Klarlund 2010) og fremfører, at en overdreven sundhedsfiksereret livsstil kan være usund. Hun finder, at den overdrevne fokusering på egen sundhed kan kamme over og give sår på sjælen. Hun finder også, at det er galt, hvis diæter og motion bliver vigtigere end samværet med familien og vennerne.

I denne artikel har jeg forsøgt at pege på, at sundhed opstår i mange andre sammenhænge end i de målrettede sundhedsaktiviteter. I denne artikel præsenteres sundhed som et resultat af en fascination for en dans, der er underlagt sociale og kulturelle strukturer, historiske forandringer, politiske strømninger, filosofiske, etiske og rituelle rammer. $\mathrm{Og}$ i det perspektiv forstås sundhed ikke kun som en målbar entydig biologisk størrelse, men som flerdimensionel, mangetydig og konfliktfyldt.

\section{LITTERATUR}

Abadi, S (2003): Milongan-omfamningarnas basar. CKM, Stockholm.

Antonovsky, A (1979): Helbredets mysterium. Hans Reitzels Forlag.

Archetti, E (2003): Playing Football and Dancing Tango: Embodying Argentina in Movement, Style and Identity. I: Sport, Dance and Embodied Identities. Ed Noel Dyck \& Eduardo Archetti. Berg, Oxford.

Christakis, N \& Fowler, J (2009): Connected: The surprising power of our social networks and how they shape our lives by. Little, Brown and Company, New York.

Hammersley; M. \& Atkinson, P.(1996): Feltmetodikk. Oslo: Ad Notam.

Hastrup, Kirsten \& Ramløv, Kirsten (1988): Feltarbejde, Akademisk Forlag.

Emerson, R.M., R. Fretz \& L. Shaw (1995): Writing Etnographic Fieldnotes. Chicago: University of Chicago Press.

Kreutz, G (2008): Does partnered dance promote health? The case of tango Argentino. J R Soc Health. 2008 Mar; 128(2):79-84.

Klarlund Pedersen, B (2010): Sygeligt fokus på krop og sundhed. Politiken, 2. januar 2010.

Kvale, S ( 2009) IntervView - Introduktion til et håndværk. 2. udgave, Hans Reitzel. 
Lave, J (1999): Læring, mesterlære, social praksis. I: Nielsen, K. og Kvale, S: Mesterlære som social praksis. København: Hans Reitzels Forlag, s. 35-54.

Lave, J \& Wenger, E (1998): Situeret læring ved legitim perifer deltagelse. I: Hermansen M. (red): Fra læringens horisont - en antologi. Århus: KLIM, s. 151-161.

McKinley P, Jacobson A, Leroux A, Bednarczyk V, Rossignol M, Fung J. (2008): Effect of a community-based Argentine tango dance program on functional balance and confidence in older adults. J Aging Phys Act. 2008 Oct; 16(4): 435-53.

Merleau-Ponty, M. (1962/2004): Phenomenology of perception. London and New York: Routledge Classics.

Toxværd, O (2006): Tango - en dans og en kultur. Rosenkilde.

Wadel, Cato (1991): Feltarbejde i egen kultur. Flekkefjord: Seek a/s.

Van Gennep, A (1908)1965: The Rites of Passage. London: Routledge.

Westergård, M (2009): Tango i Buenos Aires koder og passion. Instant Book, Stockholm.

\section{NOTER}

1. En milonga i Buenos Aires er et dansested, hvor der danses argentinsk tango og hvor der spilles både traditionel og moderne tango musik. Rummet er typisk indrettet efter sammen princip som en kabaret. Salen har i midten et dansegulv og rundt om dansegulvet er der borde og stole og der er en bar. Nogle steder er der også en scene til orkestret.

2. Informant. Hun er fast Tango- DJ på La Parctica og Milongaerne i Kolding

3. Begrebet Midmilonga har jeg kun stødt på i Perth. Klubbens bestyrelse fortalte, at en Midmilonga havde samme status som en almindelig milonga, men da den var placeret på en hverdagsaften sluttede den tidligere (kl. 23), og da den hos dem var placeret på en onsdag, havde de valgt at kalde den Midmilonga.

4. I bogen Connected: The Surprising Power of Our Social Networks and How They Shape Our Lives trækker forfat terne Christakis og Fowler (2009) en række undersøgelser frem, som viser, hvordan personer i forskellige miljøer påvirker hinanden. Et miljø, hvor flere har gode kostvaner, smitter andre i netværket til at spise sundt, mens fedme visse tilfælde kan spredes til at dække næsten 40 procent af et socialt netværk. 